\title{
Changes in New Private Law of the Czech Republic and Implementation of Basel III
}

\author{
Jindřiška Šedová \\ Masaryk University \\ Faculty of Economics and Administration, Department of Law \\ Lipová 41a, 60200 Brno, Czech Republic \\ E-mail: jsedova@econ.muni.cz
}

Received: February 15, 2019. Revised: April 17, 2021. Accepted: October 12, 2021. Published: November 16, 2021.

\begin{abstract}
Competition in the financial market puts currently new requirements for cost reduction on financial institutions. Available sources of cost reduction are seen i.a. in minimizing legal risks, which can reduce the uncertainty associated with enforcement and interpretation of legal acts, treaties and regulations in the field of contractual obligations. In this regard, banks in the Czech Republic are looking for new ways to reduce costs in the ongoing implementation of Basel II and preparation for implementation of Basel III. The central problem to which attention is focused is to ensure the required level of capital adequacy. This is conditioned i.a. by their risk management system. Capital adequacy may affect credit risk substantially. Besides others, the level of credit risk may be affected to a considerable extent by application of hedging instruments. This paper presents conclusions of the executed comparison of the existing and new private law provisions in the Czech Republic and, based on that, draws new opportunities and difficulties for banks in managing their credit risk and capital adequacy. The focus is only on the hedging instruments that may affect the activities of banks in a significant way.
\end{abstract} risk

Keywords-hedging; collatera; surety; internal rating; credit

\section{INTRODUCTION}

Banking is currently undergoing significant changes, revealing that under competitive pressure the banks must adapt to changing conditions and improve their management. Nonbanking financial companies are entering the fields where previously only banks operated and they take over banks' activities and replace them. To increased competition, banks respond by changes in product portfolio and client orientation and adaptation of existing banking systems [1]. They are forced to use new ways of organizing work and thus reduce costs. It is increasingly clear that banks are strongly oriented to profit and profitability. In parallel to these trends, convergence of regulatory laws between states is taking place due to the gradual globalization. Fundamental issues of banking supervision are discussed. In this debate there is a clash of differing opinions. On the one hand, minimum interference in the activities of bank regulators are preferred, on the other hand, there are views that prefer more precise rules and procedures required from banks. In essence, this debate can be seen as an entirely natural process of finding optimal solutions. We believe that a concept saving not only the costs for banks, but also of regulators, clients and other engaged persons should be promoted. Whether further development confirms our expectations or not may be to some extent affected by the implementation of the Basel III Accord. [2], [3].

The central question decisive for the cost of a bank is risk management. The bank in its business activities undergoes various risks: credit, interest rate, currency, liquidity and capital [4]. In this paper we will discuss the tools, which can to some extent affect the credit risk. This is a so-called credit risk arising from default on a loan relationship. Although credit risk is the oldest type of banking business risk, it still requires considerable attention and is getting more complex. It is mainly due to the increasing heterogeneity, trading volume, and the number of banking products [5], [6].

Currently, Czech banks in their management systems apply a concept of measuring capital adequacy of Basel II. Basel II rules for Czech banks are stipulated under the Act on Banks [7] and further elaborated in the Decree on prudential rules for banks, credit unions and investment firms [8].

\section{Methodology AND DATA}

According to Němec, most banks' borrowers in the Czech Republic [9] have no rating, therefore the internal rating approach is gaining in importance. This approach allows banks to determine their capital base according to their individual risk. Our attention will therefore focus on the possibility of influencing the capital adequacy of banks, primarily of such ones that use internal methods to measure the credit risk and implement the IRB approach in practice. For this method, it is typical that the bank itself determines the risk parameters. The IRB approach includes among the basic elements of risk in particular [10]:

1) Probability of Default, $P D$ - likelihood that the borrower will cease to pay in the monitored period of time.

2) Exposure at Default, EAD - the amount of expected loss which the bank will suffer in the event of default by the borrower. The total amount of assets that are at risk if the borrower fails to meet his or her obligations are monitored.

3) Loss Given Default, LGD - the loss rate in the case of a default possibly expressed as the amount of credit claims in default. 
4) Maturity, $M$ - the due date, usually the nominal due date measured in years.

For correlations observed in our analysis it is appropriate to add that the IRB approach takes both, the borrower as well as the transaction, into account. Probability of Default applies to the borrower and the other risk elements to the transaction itself. Significant is also the fact that banks can apply the aforementioned approach in two variants:

a) Foundation approach - banks carry out internal estimates for PD only, while other elements are estimates based on rules established by the regulatory authorities,

b) Advanced approach - banks can use internal estimates for all elements at the same time, however, they must meet the more stringent minimum regulatory requirements than with the foundation approach.

Internal ratings are assigned by banks on the occasion of granting the loan and at regular inspections. Assessment of risk is performed by the bank itself through its own internal rating methods. Within the IRB, exposure is classified into six categories: Corporate, Sovereign (states and their central banks, public institutions and multilateral banks), Banks and other financial institutions, Retail, Specialized lending, Equity [11], [12] .

After categorization and assessment of its characteristics (obligor and transaction), each exposure is assigned an internal rating. For this rating PD (or with the improved variant also other risk elements) is estimated as well. PD then serves as an important input into the risk weight function and the capital requirement. According Sůvová and Kadlčáková [10] bank, that have introduced credit risk measurement using IRB approach, have a lower capital requirement for that risk. We believe that the currently ongoing reform of the private law of the Czech Republic is positive for internal assessments. It brings a number of changes that significantly adjust the rules for securing debts, for creating contracts or for legal acts [13]. For creditors hedging instruments provide a higher degree of legal certainty that the debtor properly and timely meets his or her obligations. In addition, securing obligations enables banks use other hedging features which are reimbursement, incentive and punitive. In this sense, securing the best recoverability of creditor's claim is not only essential for normal trade relations, but also for the capital adequacy of funding. When deciding about whether to grant a loan to the borrower, a major role for banks is played by assessing borrower's ability to meet his or her obligations. Based on the above mentioned binding capital adequacy rules stipulated by Basel II., it may be reasonably inferred that the greater the risks the bank is exposed to in its lending business, the more own funds it has to hold. In the context of these rules, a w ell-functioning hedging belongs among the most important factors in measuring capital adequacy and has a considerable impact on the cost and availability of credit resources.

The increase in the importance of hedging instruments in the practice of banks applying internal rating approach stands out in comparison with a standard rating approach. While the standard rating approach allows using only a limited number of types of collateral (cash deposits, government and bank securities, quoted shares, gold, and residential real estate) to reduce the credit risk, internal rating approach allows banks to use other types of collateral as well. In this case, commercial real estate, mortgage chattels, stocks and trade receivables can be used. Taking into account that the internal rating approach is based on a r eliable individual evaluation of bank collateral, then necessarily there must be a sufficient guarantee of its functioning. This guarantee is performed, inter alia, by legislation on financial collateral and its appropriate application by the bank.

\section{Model Specification}

If asked what key benefits the legislation on financial collateral brings for the banks, easier enforcement must be included among the most important ones. In the context of current needs, the new Civil Code does not only complement and refine the existing legislation on financial collateral to the necessary extent, but it is also adapted to new economic conditions. In a certain perspective it is more liberal, which corresponds well with the intention of Basel II. and Basel III. as well as with the methods of internal rating [14], [15]. Impacts of the new legislation on collateral are to be seen in relation to the current level of enforcement of obligations under contracts and protection of investors (creditors) in the Czech Republic. Conditions in both fields of the business in the Czech Republic has long been considered unsatisfactory. It is evidenced by the following comparisons carried out by the World Bank (Note: data for 2013 are reported as of April 30, 2013).

TABLE I. ENFORCING CONTRACTS [16]

\begin{tabular}{|c|c|c|c|c|c|}
\hline \multirow[b]{2}{*}{ Economy } & \multicolumn{5}{|c|}{ Enforcing Contracts } \\
\hline & Year & Rank & $\begin{array}{l}\text { Time } \\
\text { (days) }\end{array}$ & $\begin{array}{c}\text { Cost } \\
\text { (\% of claim) }\end{array}$ & $\begin{array}{c}\text { Procedures } \\
\text { (number) }\end{array}$ \\
\hline \multirow{2}{*}{ Greece } & 2012 & 85 & 819 & 14.4 & 39 \\
\hline & 2013 & 87 & 819 & 14.4 & 39 \\
\hline \multirow[t]{2}{*}{ Poland } & 2012 & 84 & 830 & 19.0 & 37 \\
\hline & 2013 & 56 & 685 & 19.0 & 33 \\
\hline \multirow{2}{*}{$\begin{array}{l}\text { Czech } \\
\text { Republic }\end{array}$} & 2012 & 76 & 611 & 33.0 & 27 \\
\hline & 2013 & 79 & 611 & 33.0 & 27 \\
\hline \multirow{2}{*}{$\begin{array}{l}\text { Slovak } \\
\text { Republic }\end{array}$} & 2012 & 70 & 565 & 30.0 & 32 \\
\hline & 2013 & 69 & 545 & 30.0 & 32 \\
\hline \multirow[t]{2}{*}{ Estonia } & 2012 & 30 & 425 & 22.3 & 35 \\
\hline & 2013 & 31 & 425 & 22.3 & 35 \\
\hline \multirow{2}{*}{$\begin{array}{l}\text { United } \\
\text { Kingdom }\end{array}$} & 2012 & 21 & 399 & 24.8 & 28 \\
\hline & 2013 & 21 & 399 & 25.9 & 28 \\
\hline \multirow[t]{2}{*}{ Hungary } & 2012 & 18 & 395 & 15.0 & 35 \\
\hline & 2013 & 16 & 395 & 15.0 & 35 \\
\hline \multirow[t]{2}{*}{ France } & 2012 & 8 & 390 & 17.4 & 29 \\
\hline & 2013 & 8 & 390 & 17.4 & 29 \\
\hline \multirow[t]{2}{*}{ Germany } & 2012 & 6 & 394 & 14.4 & 30 \\
\hline & 2013 & 5 & 394 & 14.4 & 30 \\
\hline \multirow[t]{2}{*}{ United States } & 2012 & 4 & 300 & 14.4 & 32 \\
\hline & 2013 & 6 & 370 & 14.4 & 32 \\
\hline
\end{tabular}

In the following section we will focus on a comparison of the existing legislation on hedging instruments with the provisions of the new Civil Code and we will emphasize the 
changes that banks will have to implement into its procedures when entering into contractual relations from 2014.

If asked what key benefits the new legislation on financial collateral brings for the banks, easier enforcement will doubtlessly be included among the most significant ones. In the context of this state, the new Civil Code supplements or modifies the existing private law on securing obligations to the extent required. The existing regulation is not only refined but also adapted to the new economic conditions. In a certain perspective it is more liberal, which corresponds well with the intention of Basel II. and Basel III. as well as with the methods of internal rating. Major changes in hedging implemented in the new Civil Code [7] will influence primarily the following:

- enhancing benefits of securing liabilities in insolvency proceedings

- securing the liabilities to capital adequacy

- unification of current fragmented legislation and new systematic arrangement.

Changes in the new legislation on collateral are in the nature more evolutionary than revolutionary [13]. The vast majority of hedging instruments remains. The new Civil Code, in contrast to the existing legislation, distinguishes between securing and a mere affirmation of a debt. In the future, negotiating contractual penalties or acknowledgment of debt will be only considered an affirmation of the debt. Affirmation of debt mainly functions as an incentive and penalty. It guarantees that the debtor will meet his obligations in excess. These instruments are not inherently protective, as in the case of default, the creditor neither has the opportunity to use the collateral nor has the right to preferential satisfaction of the claim in insolvency proceedings based on them. In contrast, collateral functions as a hedging instrument and a reimbursement feature. It guarantees that the debtor pays the debt back. Another innovation is the introduction of collateral administrator who can be provided with the collateral for the benefit of the creditor. It is expected that this option will be welcomed by banks engaged in syndicated financing, i.e. in a situation where multiple creditors provide a secured loan to a single borrower [9].

More accurate is also the new definition of who an eligible guarantor is and to what value the assets are an eligible collateral. An eligible guarantor will be considered a p erson who can be sued and has suitable assets. Eligible collateral will be assets up to two-thirds of the normal price, building lot and immovable asset used for business purposes up to half the usual price, security with a secure income up to two-thirds of the normal value and deposits in banks up to the insurance.

Maintaining a certain continuity in the legislation on collateral and thus necessary legal certainty in contractual practice can be evaluated positively. The following previously known hedging instruments can also be used in the future:

- lien

- surety

- financial guarantee
- security transfer of one's right

- agreement on deductions from wages or other income.

\section{A. Lien}

The very nature of existing legislation on collateral was not affected by the new legislation. Creditor will continue to have the opportunity to obtain satisfaction from the proceeds of liquidation of the lien to the agreed amount or the amount of the claim with accessories. Only certain partial aspects of the collateral are changed. Rather significant changes in the legislation on collateral are as follows:

\section{1) Refining prohibiting conduct}

- Conduct prohibiting establishment of a lien affecting a third party. Such conduct will be possible only if the prohibition is registered in the register of pledges or in a public list. The model for this provision was collateral legislation in the Slovak Republic. Its use is expected mainly in insolvency proceedings [17].

- Conduct prohibiting burden on or disposal of an asset. The new legislation explicitly states that this prohibition applies only between the parties and may be negotiated only at a reasonable time and in the interests of a party that is worthy of legal protection. Similarly, the prohibition is valid even if it $\mathrm{w}$ as established for the duration of the Trust Fund, the Trust Succession and Representation [18].

- Prohibiting arrangements under which the debtor or the pledgor must not pay back the pledge. In particular, attention is drawn to the prohibition of a clause stating that the creditor could sell the pledge in any manner or keep it for an arbitrary or predetermined price when the secured debt has not been mature yet. It can therefore be inferred that after the secured debt matures, the parties may agree on a contract forfeiture of the pledge. This option will not be provided if the pledgor or lien debtor is a consumer or a person who is a small or mediumsized enterprise.

\section{2) Assets as Pledges}

Every asset that can be traded may be used as a pledge. New legislation will have to be viewed in the context of the new definition of an asset. An asset in the legal sense is considered anything that is different from people and serves the needs of people. Assets can be tangible or intangible, movable or immovable. Such designation of assets will allow a lien on a wide range of assets. The new legislation will also enable the subject of pledge to be a set of assets that changes over time. Such set can be e.g. stocks or mobile inventory. The set of assets will be a pledge (a floating charge) in the state in which they are at that moment. Abroad, this innovative hedging instrument proved and is commonly used.

\section{3) Agreement on the Order of Lien and Substitution of Lien.}

New to the lien is the possibility to replace the original lien for a new one in the same order, if not exceeding the original debt. 
Pledgees may also negotiate in writing a new order of liens, if there are several on a pledge.

\section{4) Share in a Corporation, Securities, Account of} Registered Securities and Receivable as Pledges.

These assets have special provisions stipulated in the new Civil Code. E.g. it will be possible to secure a lien on receivables and have it entered in the register of pledges. This register is not public.

\section{5) Future Collateral}

It will be possible to set up the lien explicitly also on assets to which the pledgor ownership only arises in the future. The lien arises at the moment of acquisition of this ownership. It will be possible to enter the future agreement in the land register or the register of pledges.

TABLE II. RESOLVING INSOLVENCY [19]

\begin{tabular}{|c|c|c|c|c|}
\hline \multirow[b]{2}{*}{ Economy } & \multicolumn{4}{|c|}{ Resolving Insolvency } \\
\hline & Year & Rank & $\begin{array}{r}\text { Time } \\
\text { (years) }\end{array}$ & $\begin{array}{c}\text { Recovery rate } \\
\text { (cents on the } \\
\text { dollar) }\end{array}$ \\
\hline \multirow[t]{2}{*}{ Greece } & 2012 & 50 & 2 & 41.8 \\
\hline & 2013 & 58 & 2 & 44.5 \\
\hline \multirow[t]{2}{*}{ Poland } & 2012 & 91 & 3 & 31.5 \\
\hline & 2013 & 37 & 3 & 54.5 \\
\hline \multirow{2}{*}{$\begin{array}{l}\text { Czech } \\
\text { Republic }\end{array}$} & 2012 & 34 & 3.2 & 56.0 \\
\hline & 2013 & 34 & 3.2 & 56.3 \\
\hline \multirow{2}{*}{$\begin{array}{l}\text { Slovak } \\
\text { Republic }\end{array}$} & 2012 & 36 & 4.0 & 54.3 \\
\hline & 2013 & 38 & 4.0 & 53.6 \\
\hline \multirow[t]{2}{*}{ Estonia } & 2012 & 76 & 3.0 & 36.9 \\
\hline & 2013 & 72 & 3.0 & 38.5 \\
\hline \multirow{2}{*}{$\begin{array}{l}\text { United } \\
\text { Kingdom }\end{array}$} & 2012 & 6 & 1.0 & 88.6 \\
\hline & 2013 & 8 & 1.0 & 88.6 \\
\hline \multirow[t]{2}{*}{ Hungary } & 2012 & 67 & 2.0 & 39.2 \\
\hline & 2013 & 70 & 2.0 & 38.8 \\
\hline \multirow[t]{2}{*}{ France } & 2012 & 46 & 1.9 & 45.8 \\
\hline & 2013 & 43 & 1.9 & 48.4 \\
\hline \multirow[t]{2}{*}{ Germany } & 2012 & 12 & 1.2 & 82.7 \\
\hline & 2013 & 19 & 1.2 & 78.1 \\
\hline \multirow[t]{2}{*}{ United States } & 2012 & 15 & 1.5 & 81.5 \\
\hline & 2013 & 16 & 1.5 & 81.5 \\
\hline
\end{tabular}

\section{6) New Specification of Debt}

An innovation is the possibility to secure not only a certain amount of debt, but a debt the amount of which can be determined at any time during the term of the lien. Secured debt may be financial and non-financial, suspended or even one that has yet to arise in the future. Secured debt may also be a certain type of debts arising for the debtor at a certain period of time, as well as various debts arising for the debtor on the same legal grounds.

Hereby the possibilities of banks to secure various debts arising from different reasons at different times are extended. The new legislation responds to up-to date methods of financing, such as overdrafts, revolving, etc.

\section{7) Execution of Lien}

Execution of the lien is expanded and refined. If there is no agreement on execution of the lien, the lienor is entitled to obtain satisfaction from the proceeds of liquidation of the lien at public auction or sale of the asset under lien under another Act. Newly it is possible to execute lien in the way on which the lienor and the lienee, i.e. lien debtor, have agreed in writing. Such a broad concept of the possibility of selling the pledge is conditioned by the obligation of the lienor to proceed in the sale with professional care in the interest of both, his own and of the lien debtor.

\section{B. Surety}

Like the lien, the continuity with the existing legislation is apparent. In this case, the basis is in the provisions on surety of the Commercial Code [20]. The debtor's surety will still be considered a person who declares to the creditor to satisfy him or her, if the debtor fails to satisfy his or her debt to the creditor. Creditors in securing should remember that the surety statement must be in writing and that the surety cannot be asked to pay anything, if the statement is not accepted. Surety may also by provided for future or conditioned debts.

We expect that banks will appreciate the two innovations regarding surety, namely:

- Surety can be provided for a set debts of a certain type arising for the debtor at a certain time.

- It will be possible to arrange surety for a set of various debts on the same legal grounds.

- The legislation on surety also refines subrogation. The following will come in force:

- By satisfying the debt, the surety enters the creditor's rights (including accessories, security and other rights associated with the claim) and has the right to be paid by the debtor for what he or she has satisfied.

- Where the surety only satisfies a part of the debt, he or she may only require a settlement of what he or she has satisfied for the debtor. However, the original creditor has the right to offset the balance of their claims in preference to the new creditor.

- Where several persons satisfied the debt for the debtor, each one is entitled to a proportionate share of compensation according to the satisfaction they provided for the debtor.

- Enforcing Contracts 
TABLE III.

RESOLVING INSOLVENCY [21]

\begin{tabular}{|c|c|c|c|c|}
\hline \multirow[b]{2}{*}{ Economy } & \multicolumn{4}{|c|}{ Getting Credit } \\
\hline & Year & Rank & $\begin{array}{l}\text { Strength of legal } \\
\text { rights index } \\
(0-10)\end{array}$ & $\begin{array}{c}\text { Depth of credit } \\
\text { information index } \\
(0-6)\end{array}$ \\
\hline \multirow[t]{2}{*}{ Greece } & 2012 & 50 & 80 & 4 \\
\hline & 2013 & 58 & 83 & 4 \\
\hline \multirow{2}{*}{ Poland } & 2012 & 91 & 4 & 9 \\
\hline & 2013 & 37 & 4 & 9 \\
\hline \multirow{2}{*}{$\begin{array}{l}\text { Czech } \\
\text { Republic }\end{array}$} & 2012 & 34 & 52 & 6 \\
\hline & 2013 & 34 & 53 & 6 \\
\hline \multirow{2}{*}{$\begin{array}{l}\text { Slovak } \\
\text { Republic }\end{array}$} & 2012 & 36 & 23 & 9 \\
\hline & 2013 & 38 & 23 & 9 \\
\hline \multirow[t]{2}{*}{ Estonia } & 2012 & 76 & 38 & 7 \\
\hline & 2013 & 72 & 40 & 7 \\
\hline \multirow{2}{*}{$\begin{array}{l}\text { United } \\
\text { Kingdom }\end{array}$} & 2012 & 6 & 1 & 10 \\
\hline & 2013 & 8 & 1 & 10 \\
\hline \multirow[t]{2}{*}{ Hungary } & 2012 & 67 & 52 & 7 \\
\hline & 2013 & 70 & 53 & 7 \\
\hline \multirow[t]{2}{*}{ France } & 2012 & 46 & 52 & 7 \\
\hline & 2013 & 43 & 53 & 7 \\
\hline \multirow[t]{2}{*}{ Germany } & 2012 & 12 & 23 & 7 \\
\hline & 2013 & 19 & 23 & 7 \\
\hline \multirow[t]{2}{*}{ United States } & 2012 & 15 & 4 & 9 \\
\hline & 2013 & 16 & 4 & 9 \\
\hline
\end{tabular}

\section{Financial Guarantee}

Financial guarantee is a new hedging instrument which will be particularly welcome in bank financing. It is expected that it will often be required from business corporations, while ensuring debts of companies from the group instead of the regular surety. The main difference, compared to the simple surety, is the fact that the issuer is liable for the satisfaction of the secured debt only to the extent and under the conditions specified in the letter of guarantee.

The financial guarantee is based upon the existing bank guarantee in the Commercial Code. The essential difference lies in the fact that it allows abstract guaranties also to entities other than banks and:

- it will now be possible to transfer the right to the satisfaction from the guarantee, whereas previously only the secured claim,

- now also the right to apply a bank guarantee can be transferred.

\section{Security Transfer of One's Right}

Due to the very limited provisions on the security transfer of one's right and its quite complicated interpretation, the banks had in its current contractual practices often rely on findings from case law. By the security transfer of one's right, the debtor or a third party secures the debt by temporarily transferring their right to the creditors. Unlike the lien, by transferring one's right for security reasons, the debtor loses his or her ownership. The new legislation of security transfer of rights does not contain significant changes, nevertheless, it is more detailed and enriched with some of the conclusions of case law.
Changes are found primarily in the following portions of legislation on security transfer of rights:

- Security transfer of rights is a transfer with a termination condition that the debt will be satisfied.

- Unless the secured debt has been paid, the transfer of one's right becomes unconditional.

- Security transfer of one's right to an asset registered in a public register arises upon an entry into this register.

- After the security transfer of one's rights expires, the creditor will enable the person who provided the security to exercise his or her rights in the previous extent.

- In case the market value of the security apparently exceeds the amount of secured debt, the creditor shall pay an amount equal to the difference to the person who provided the security.

Though the new Civil Code does not expressly regulate the transfer of one's right to secure the debt, it will undoubtedly be used in practice [13]. The essence of security assignment of the claim is based on the following assumptions:

- The creditor may assign an entire claim or part thereof by a contract as an assignor to another person (the assignee) without the consent of the debtor.

- Upon assigning the claim, the assignee acquires also its accessories and rights associated with the claim, including its security.

- It is also possible to assign a set of claims present, as well as future.

- Unless excluded by the nature of the contract, either party as assignor may transfer their rights and obligations under the contract to a third party, if the transferred party agrees and if not yet satisfied.

\section{E. Agreement on Deductions from Wages or Other Income.}

Current legislation on the payroll deductions limits the use of hedging instruments to prevent excessive demands on employers. The new law considers agreements on deductions from wages or other income as one of the important tools to secure consumer loans. In practice, banks can therefore act as a suitable retail tool to secure consumer loans. The new concept of legislation is mainly based on the following conditions:

- It is now possible to secure a debt by an agreement on deductions from wages or salary (nowadays it is an option only to satisfy the maintenance claim).

- An agreement between the lender and the borrower is necessary.

- Deductions shall be no more than half the wages and salary.

- The agreement requires a prior consent of the employer, unless they are deductions from wages to satisfy the employer's rights. 
- The costs are borne by the employer, but the costs of the second and any other agreements are already charged to the debtor.

\section{CONCLUSIONS}

The new Civil Code provides new legislation governing obligations and their security for banks, but also other entities. In many aspects, the new concept of private law corresponds to the new trends that are gaining in bank management. Generally speaking, on the one hand, the degree of freedom of contract is increasing, but on the other hand, the emphasis on protecting the weaker party is increasing simultaneously. Based on a comparison of the existing and new legislation on collateral, it may be inferred that the new legislation offers more liberal concept of security for banks. It provides new concepts of security for practice, complements and specifies in more detail the existing legal hedging instruments, enables more efficient use of the existing instruments with regard to the greater spectrum of the collateral, conditions of security, the scope of coverage, risks, etc. This paper presents a more detailed specification of these differences. The presented advantages of the new legislation allow banks to

\section{ACKNOWLEDGMENT}

This paper was elaborated within the framework of project OPVK: Innovation of teaching law in the fields of Finance and Financial business in the ESF MU No. CZ.1.07/2.2.00/15.0189

\section{REFERENCES}

[1] P. Vinš, P. Rating. 1. Vyd. Praha: C. H. Beck, 2005. 109 s. ISBN 807179-807 X.

[2] J. Bauerová, Nejen banky čeká další vlna regulací. /online/. Bankovnictví. 2009. [On-line]. Available at: http://bankovnictvi.ihned.cz/c1-38703210-nejen-banky-ceka-dalsi-vlnaregulace

[3] J. Jílek, Finanční rizika. Praha: Grada Publishing, 2000, p. 635. ISBN 80-7169-579-3.

[4] F.Dierick, F.Pires, M. Scheicher, K.G. Spitzer, „,The Nwe Basel Capital Framework and its Implementation in the European Union“. Occasional Paper Series No 42, European Central Bank, 2005

[5] C. Stephanou, C., J. C. Mendoza, ,Credit Risk Measurement Under Basel II: An Overwiew and Implementation Issues for Developing Countries“. Working Paper 356, World Bank, 2005

[6] [7] The Act on Banks (Act No. 120/2007 Coll, on banks)

[7] [8] The Decree on prudential rules for banks, credit unions and investment firms. (Decree No 123/2007 Coll, on prudential rules for banks, credit unions and investment firms)

[8] R. Němec, „Zajištění závazků podle nového občanského zákoníku“. Právní rádce. 2011. [On-line]. Available at: http://pravniradce.ihned.cz/c1-52130100-zajisteni-zavazku-podlenoveho-obcanskeho-zakoniku. Hospodářské noviny IHNED ISSN 1213 -7693 .

[9] N. Kadlčáková, H. Sůvová, Dopady jednotlivých přístupů. Bankovnictví 16.5.2002, p. 16. [On-line]. Available at: http://www.cnb.cz/cs/verejnost/pro_media/clanky_rozhovory/media_20 02/cl 02 020516c.html
[10] Basel Committee on Banking Supervision: A new Capital Adequacy Framework. 1999. [On-line]. Available at: http://www.bis.org/publ/bcbs65.pdf.

[11] Basel Committee on Banking Supervision: International Governance of Capital Measurement and Capital Standards 2004. [On-line]. Available at: http://www.bis.org/publ/bcbs107.pdf. ISBN web: 92-9197-669-5

[12] B. Havel, K. Smolíková, Zákon o obchodních korporacích s aktualizovanou důvodovou zprávou. Ostrava: Sagit 2012, p. 212-288. ISBN 978-80-7208-923-9.

[13] Financial Stability Institute. 2008 FSI Survey on the Implementation of the new capital adequacy Framework in non-Basel Committee member coutries. [On-line]. Available at: http://www.bis.org/fsi/fsiop2008.pdf?noframes=1

[14] The Basel Committee response to the financial crisis: report to the G20.2010. [On-line]. Available at: : http://www.bis.org/publ/bcbs179.htm

[15] World Bank. Database Doing Business - Enforcing Contracts 2012 , 2013: Available at: http://www.doingbusiness.org/

[16] Civil Code (Act No. 89/2012 Coll., on civil code, section 1309)

[17] Civil Code (Act No. 89/2012 Coll., on civil code, section 1761)

[18] World Bank. Database Doing Business - Resolving Insolvency 2012, 2013: Available at: http://www.doingbusiness.org/

[19] Bussines corporation act (Act No. 90/2012 Coll., on Bussines Corporation).

[20] World Bank. Database Doing Business - Getting Credit 2012, 2013: Available at: http://www.doingbusiness.org/

\section{Creative Commons Attribution License 4.0 (Attribution 4.0 International, CC BY 4.0)}

This article is published under the terms of the Creative Commons Attribution License 4.0 https://creativecommons.org/licenses/by/4.0/deed.en_US 